\title{
ÉVEZREDEK A TALPUNK ALATT \\ Ásatás az Irgalmasrend budai kórházának udvarán
}

\section{Bencze Zoltán - Fényes Gabriella - Kurunczi Mónika}

Magyar Régészet 9. évf. (2020), 1. szám, pp. 21-29. doi: https://doi.org/10.36245/mr.2020.1.4

Az ásatás területe a Duna partján, a budai dombok lábánál, hévforrások közelében, kikötésre alkalmas területen fekszik, amely a középkorban és a római korban is fontos telepitö tényezö volt. A Budapest szivében folyó ásatás a fơváros múltjának mintegy kétezer éves történetébe engedett betekintést. A munka során ennek a sok évszázados történetnek az egymásra rakódott emlékeit találtuk meg. A középkorban a területet Budafelhévíznek nevezték, de ennek eddig - az 1906-ban elökerült Szentháromság-templomon kivül - régészeti szempontból feltárt maradványát nem ismertük. A római korban ugyan közvetett adatokból sejthető volt a terület lakottsága, de beépitettségéröl régészeti adattal alig rendelkeztünk. A mostani kutatás a középkori és a római kori topográfia szempontjából egyaránt új és jelentös eredményeket hozott.

Budapesten a II. kerület Frankel Leó út 17-19. szám alatt a meglévő kórházudvar beépítéséhez kapcsolódó építkezést megelőzően, 2019 májusa és októbere között a Budapesti Történeti Múzeum régészeiként nagy felületü feltárást végeztünk (1. kép). A mai kórházépület udvarán két és fél méter 20. század eleji építési törmeléket kellett eltávolítani. Szerencsére az újkori közmüvek ebben a feltöltésben találhatóak, így régészeti rétegeket nem roncsoltak. A törmelékben barokk szobortöredékek és egy török sírkő turbánrésze is elökerült. A feltöltés alatt megtaláltuk a korábbi, 1806 és 1815 között épített kórház maradványait. Ez az épület a maitól délebbre állt, az 1899-ben visszabontott fö- és pincefalai az

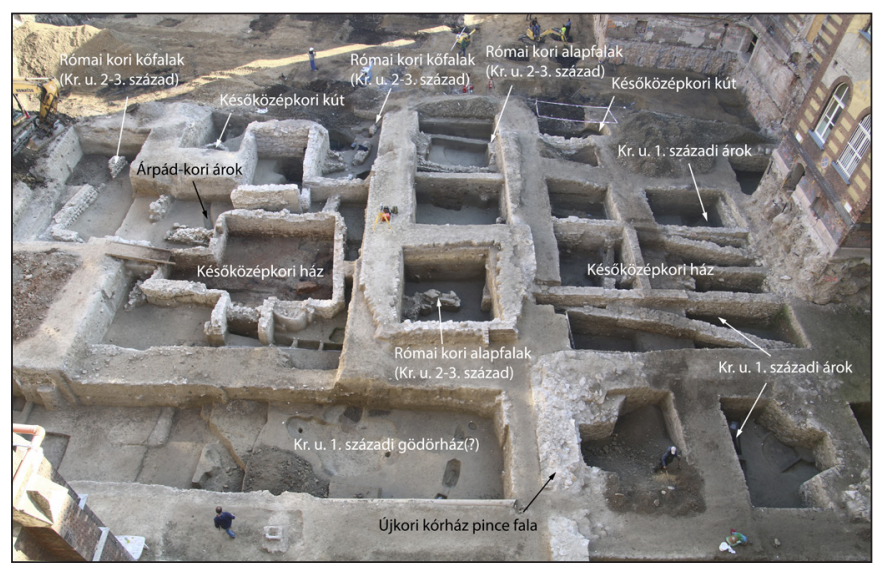

1. kép. Ásatás madártávlatból: kétezer év épített öröksége a Budai Irgalmasrendi Kórház udvarán (fénykép: Komjáthy P.) ásatás során az udvar déli egyharmadában kerültek elő. Az épület északi előterében L alakú lekövezett tér helyezkedett el, amely 19. századi térképeken is jól azonosítható. Budapest 1873-as kataszteri térképe szerint a tér északi oldalán kertek húzódtak. Az újkori épületek hiányának köszönhetjük, hogy az ásatási terület nagyobb részén a régészeti korú emlékek jó állapotban maradtak meg. Az újkori építkezés alatt sárga agyagos feltöltés húzódott, alatta dunai áradások szürke iszapos rétegei következtek. A felső rétegekbe még újkori beásások mélyedtek; az alsókban kisebb-nagyobb komolyabban megépített, vagy teljesen esetleges tüzhelynyomok voltak, amelyek a középkori rétegeket fedték.

\section{A KÖZÉPKORI BUDAFELHÉVIIZ MARADVÁNYAI}

Az ásatási terület egykor közvetlenül a Duna partján helyezkedett el. Már a mai udvar keleti része is a folyó árteréhez tartozott. Az udvar nyugati sávjában több, mint 50 m hosszan követhetö, észak-déli irányú, 5-7 m szélességü, a déli végén nyugat felé kanyarodó, lekövezett útfelületet találtunk (2. kép). Ennek felületéről és kövei közül sok középkori lelet került elö: érmek, patkók, bronz gyertyatartó töredéke, kard markolatgombja. Az utat kisebb-nagyobb kerekded kövekből vagy kőtörmelékből rakták, melyek közét kaviccsal töltötték ki, és több helyen megújították (3. kép).

Az út keleti oldalán két épületet tártunk fel. A nyugati oldala jórészt a mai kórházépület alá esik, így ott csak az északnyugati részén sikerült egy 4,50 m hosszú, a sárga agyagos altalajba kötőanyag nélkül rakott pincefalat találnunk. 
Bencze Zoltán - Fényes Gabriella - Kurunczi Mónika • Évezredek a talpunk alatt

Az út keleti, Duna felöli oldalán, a mai udvar közepén egy kétszintes ház állt. Alsó, félpince jellegü részének a kőfalai $180 \mathrm{~cm}$ magasságig maradtak ránk (4. kép). Az alapterülete 9,80×6 m volt. A falai ,,szedett-vedettek", részben már meglévő falra épültek, a vastagságuk is eltérő, de többnyire 60-70 cm között ingadozik, kívül több helyen zsaluzat nyoma is látszik. A kő anyaga vegyes, még egy őrlőkőtöredéket is beépítettek. Az északkeleti oldalán egy ablaknyílás került elő, melyet később befalaztak. A nyugati oldalon az utcaszintről lejárat nyílt. A ház másik bejárata az északi oldalon vezetett a felső szintre. A falak között $1 \mathrm{~m}$ vastag, vörös, átégett, paticsos pusztulási réteg volt, amely a beszakadt felső szint maradványaiból képződött, benne a mindennapi élet használati tárgyaival. Ebböl a ház szemeskályhájának töredékei, ablakának vasrácsa, üveg ablakszemek darabjai, ajtóvasalások és két kulcs mellett sok tégla is elökerült, amely a ház pusztulása idején a pince boltozatát alkothatta. A vörös színű omladékréteg alatt talált szürke fasze-
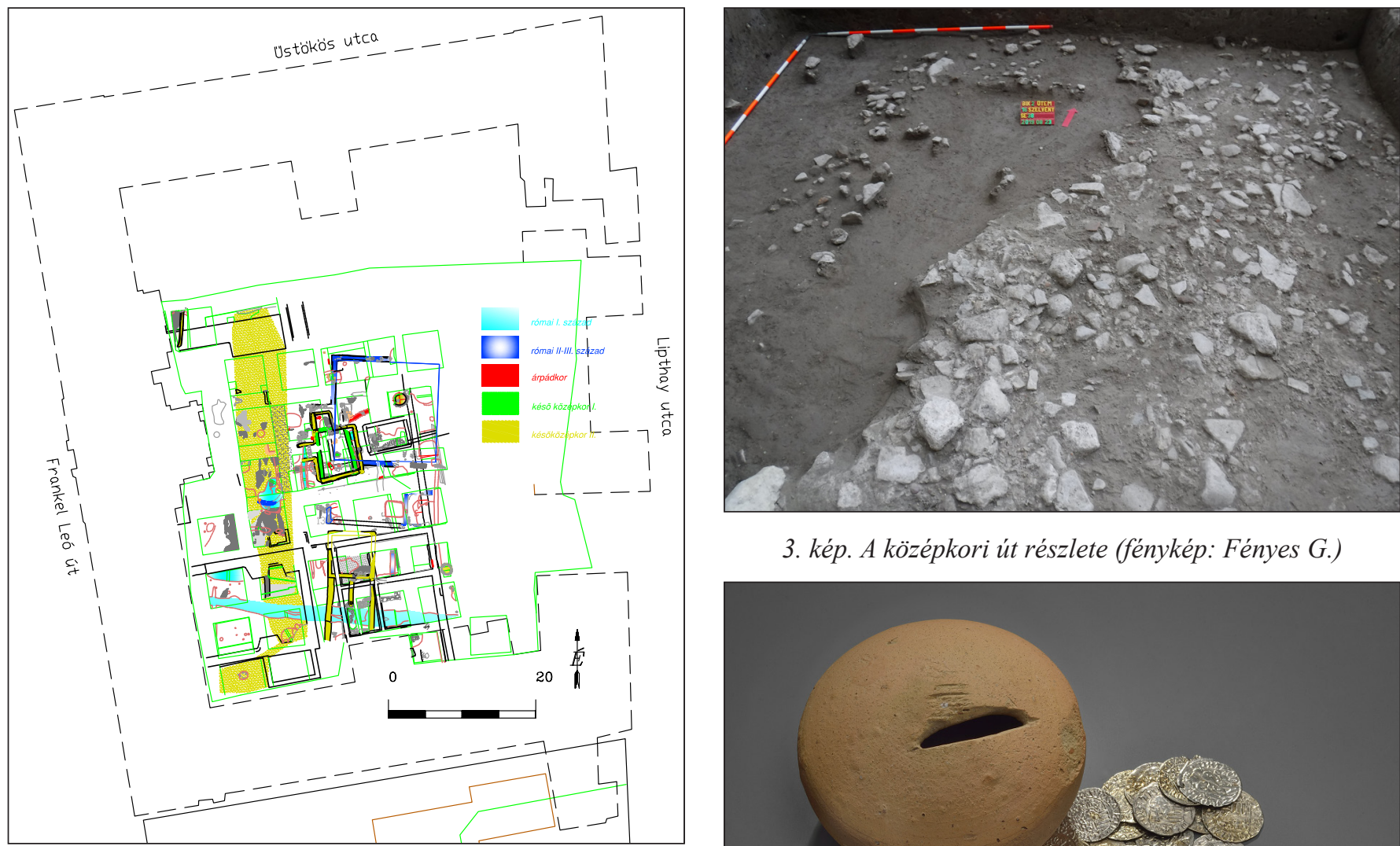

3. kép. A középkori út részlete (fénykép: Fényes G.)

2. kép. Az ásatáson elökerült régészeti objektumok és keltezésük (rajz: Viemann Zs.)
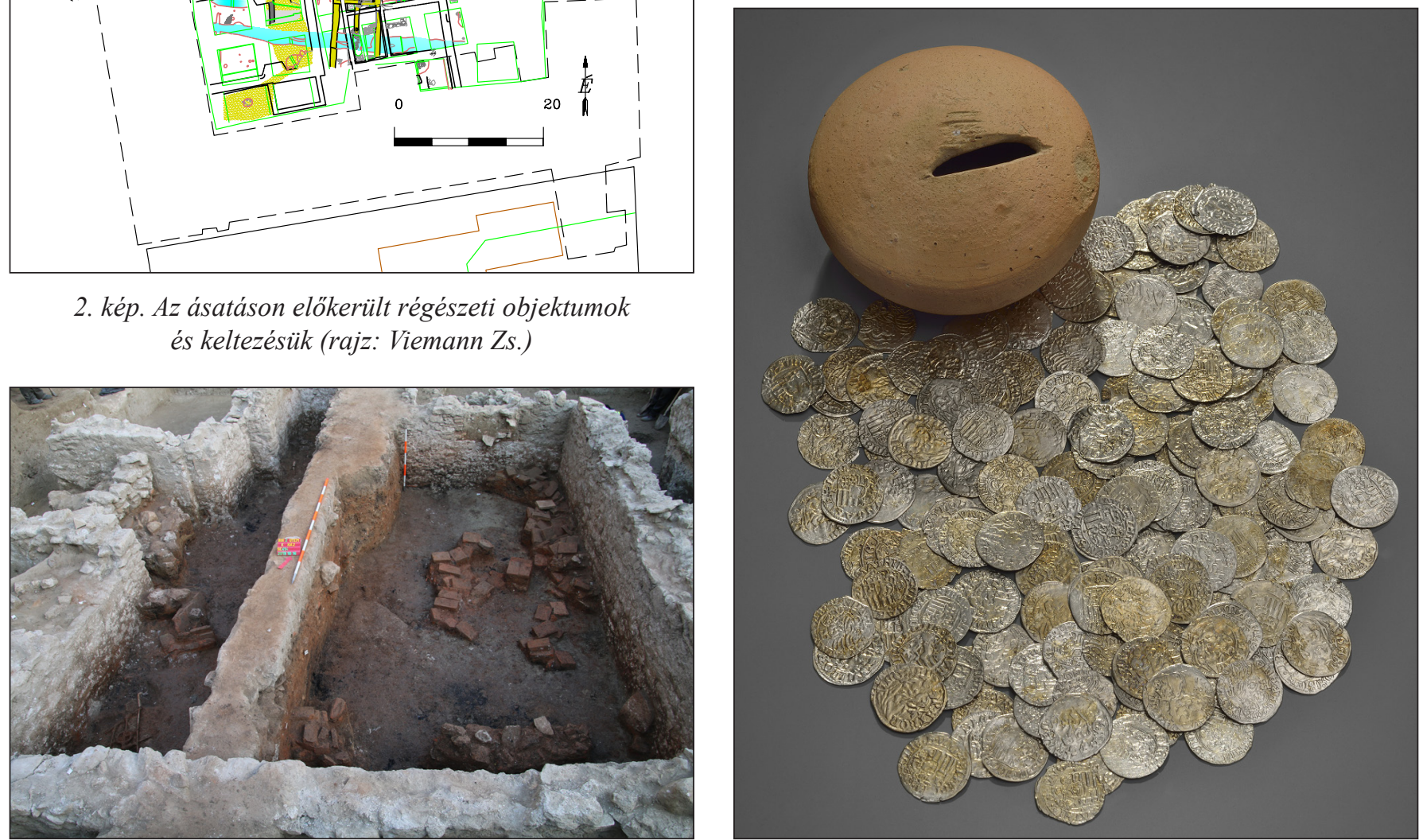

4. kép. A kórházudvar közepén feltárt késö középkori ház maradványai (fénykép: Komjáthy P.)

5. kép. Cseréppersely a késö középkori ház pincéjének padlójáról Hunyadi Mátyás pénzeivel (fénykép: Tihanyi B.) 
Bencze Zoltán - Fényes Gabriella - Kurunczi Mónika • Évezredek a talpunk alatt

nes agyagréteg a ház egykori padlószintje lehetett. Innen került elö egy pénzzel teli cseréppersely (5. kép). A restaurátorok ügyességének köszönhetően a vereteket roncsolásmentesen sikerült belöle kibányászni. A 318 darabos lelet 14 db 15. század eleji, Aquileiaban vert denarral indul, és II. Ulászló pénzeivel zárul a 16. század elejéről. A pénzek többségét Hunyadi Mátyás idején verték. Az épületet a 16. század eleji pusztulása után felújították, és tovább használták - feltehetően a nyugati bejárat melletti kemence is csak ekkor épült.

Ettől az épülettől délre egy másik késő középkori ház állt (2. kép). A falaira azonban ráépültek az újkori kórházépület pincefalai, ezért erről kevesebb információval rendelkezünk. Az épület az utca vonalával párhuzamos, tájolása nem a másik középkori házzal, sokkal inkább a római kőfalakkal egyezik meg. Észak-déli hossza minimum 15 m, szélessége kelet-nyugati irányban $6,5 \mathrm{~m}$. Az északi része alá volt pincézve, amelyben vörös, vastag pusztulási réteget találtunk.

Az utca keleti oldalát alkotó házakhoz kutak is tartoztak. A Duna partján két kutat tártunk fel, melyeket lapos, hasított kövekböl raktak ki, körülötte kavics szüröréteggel. A déli kút belső átméröje 110-150 cm között változik, 4,5 m mélyen elökerült alja kavicsozott (6. kép). Az északi kút kissé ovális, legnagyobb belső átmérője $170 \mathrm{~cm}, 3 \mathrm{~m}$ mélyen

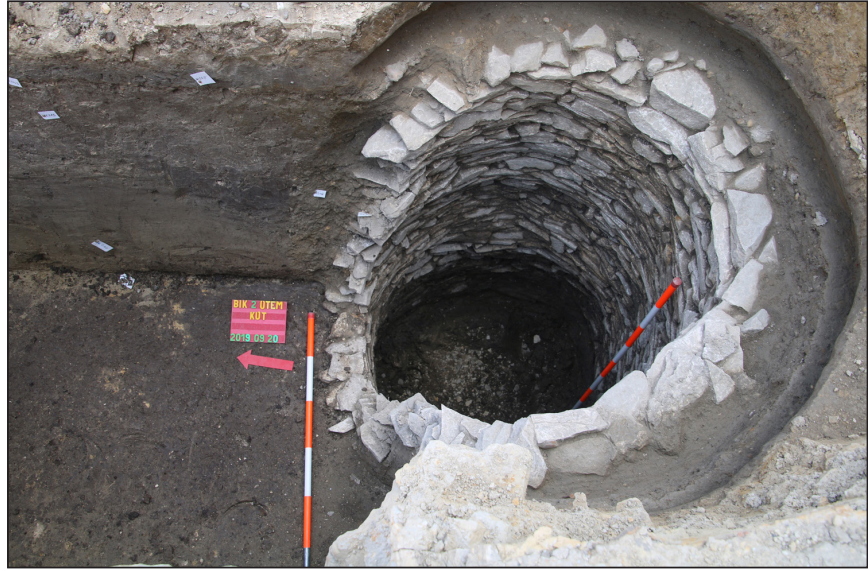

6. kép. Középkori kút kibontása közben (fénykép: Komjáthy P.)

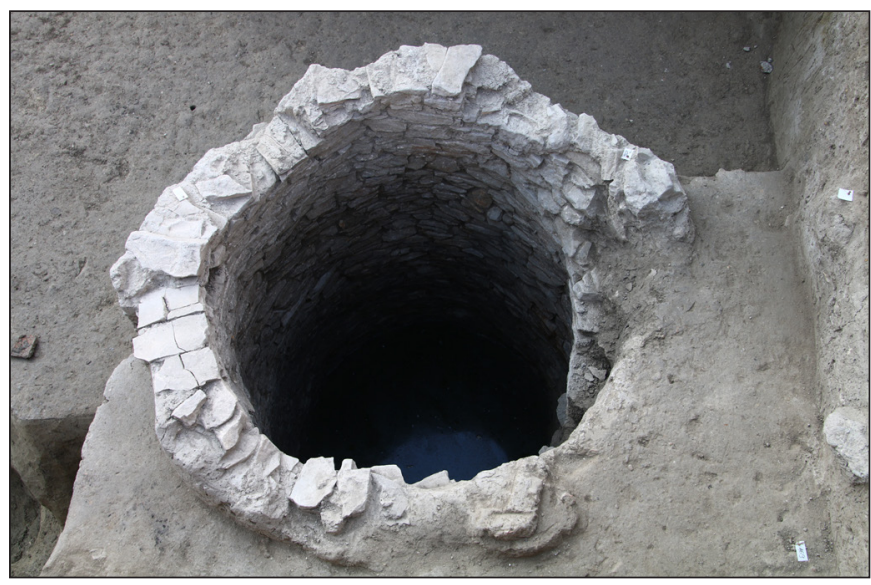

7. kép. Középkori kút (fénykép: Komjáthy P.)

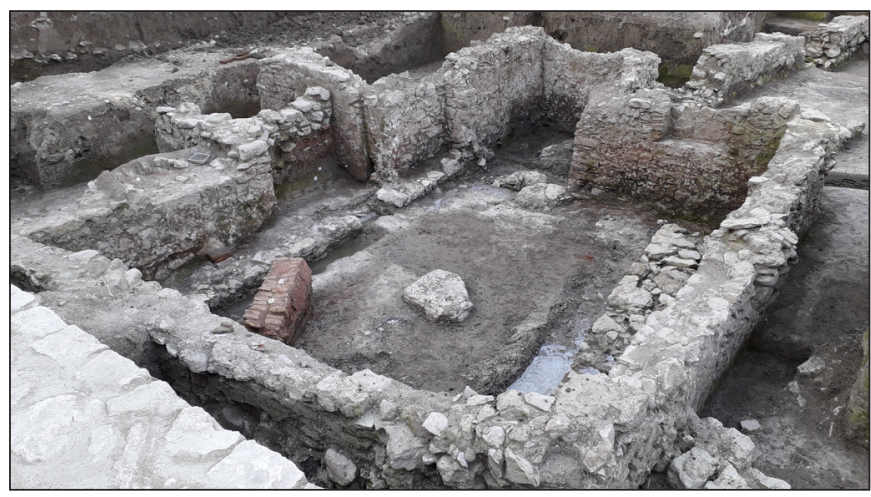

8. kép. Korábbi középkori falmaradványok a késö középkori ház alatt (fénykép: Fényes G.) rint a területet már az Árpád-korban is intenzíven használták, ebből az időszakból csupán egy objektumot ismerünk, viszont a korabeli rétegből szép leletanyaggal rendelkezünk. A kétszintes késő középkori ház és annak kútja között egy kelet-nyugati árok került elő, amelyben a 13. századi házikerámia mellett egy világoszöld mázas aquamanile-töredéket is találtunk.

\section{A RÓMAI KORI TELEPÜLÉSNYOMOK}

A mai kórházudvar közepén lévő középkori épületet egy $15 \times 15$ méteres római kőépületbe építették bele oly módon, hogy a ház területén azt teljesen visszabontották (1-2. kép). Ennek elbontott köveit minden 


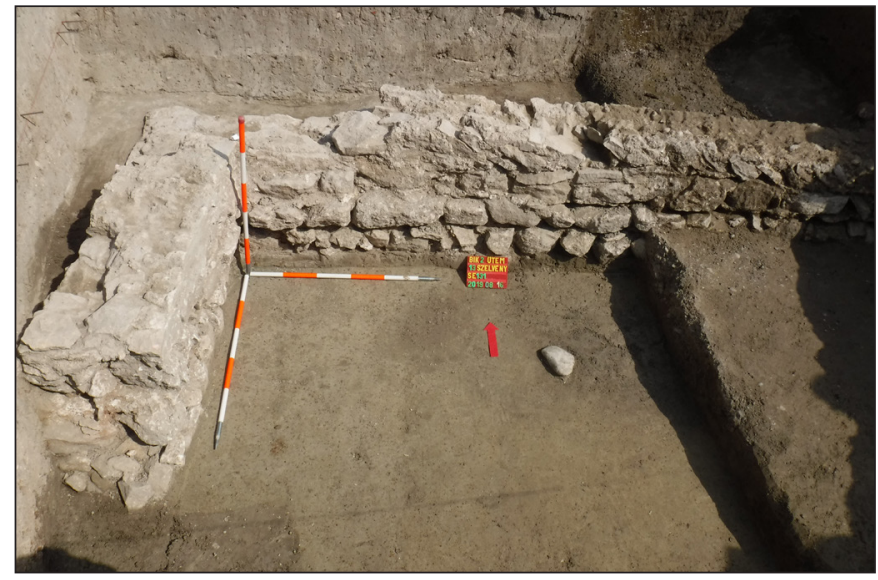

9. kép. Római falak a középkori épület körül (fénykép: Fényes G.)

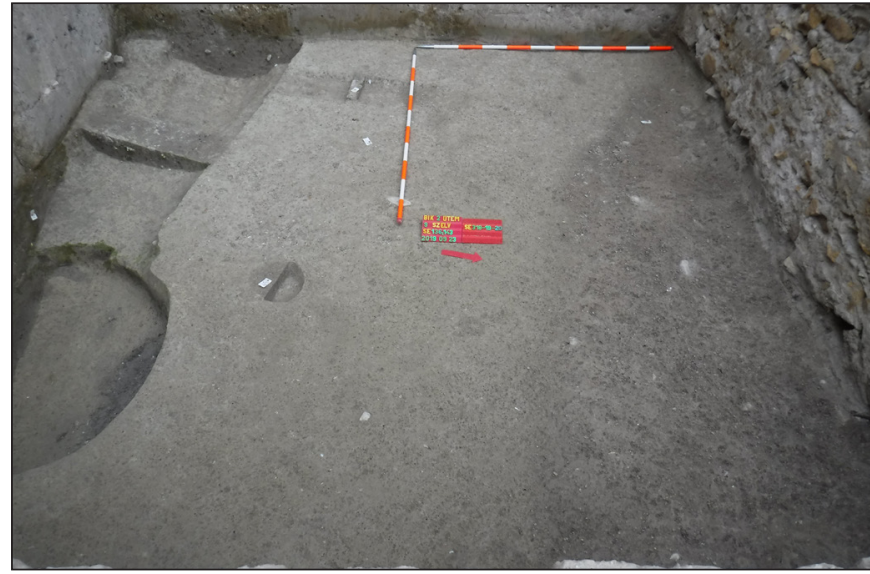

10. kép. 1. századi objektumok bontás közben (fénykép: Fényes G.)

bizonnyal fel is használták az új építkezéshez. A többi részen az ókori falakat meghagyták, csak átjárókat nyitottak rajta. A római épületet a leletanyag alapján a 2-3. században használták, de a későbbi területhasználat miatt a funkciójáról, a belső felosztásáról semmilyen információval nem rendelkezünk. A római fal $60 \mathrm{~cm}$ széles, köveit részben halszálka falazattal (opus spicatum) rakták (9. kép). E római épület mellett kőalapozású épületek is állhattak, amelyekből csak az alsó kősor, vagy annak áradások által elvitt törmelékei maradtak meg.

A mai kórházudvar déli és délnyugati részén korábbi földbe mélyített objektumokat, árkokat, gödröket, cölöplyukakat találtunk (2. kép). A középkori út és a római kőépítkezés nyomai alatt egy 4,70 m hosszú és 3,50 m széles gödörház(?) került elö, melyből egy ló csontvázának részletét, egy korai vörös bevonatos kancsót és egy 1. századi fibulát bontottunk ki. A mai udvar déli felén, az eredeti terepszint némileg kiemelkedő részén, a középkori és újkori építkezések alatt egy $34 \mathrm{~m}$ hosszan követhető $2 \mathrm{~m}$ széles, kelet-nyugati irányú árkot, pontosabban annak teknős, lapos alját találtuk meg (10. kép). Ettől északra egy nagyobb gödör részletét tártuk fel, melynek funkciója nem ismert, mert az újkori kórház fala a nagyobb részét elvitte. Ezekből az objektumokból kevés, de nagyon jellegzetes leletanyag származik: a helyi kelta őslakosság legkésőbbi edényei és a római hódítók nagyon jó minőségü, minden bizonnyal importált tárgyai (gladiátorpárt ábrázoló Loeschke I/B típusú mécses, korai cikkádafibula, dél-galliai terra sigillata, Dressel 2-4 típusú boros amphora). A jelenségeket egy korai érem (Tiberius vagy Cladius császáré?) is keltezi.

\section{A LELŐHELY A KÖZÉPKORI TOPOGRÁFIÁBAN}

A korábbi kutatások alapján valószínűleg a mai Margit híd budai hídföje táján helyezkedett el Gézavására. II. Géza király 1148-ban kelt, de 1253-as átiratban fennmaradt oklevelében (MDCBP I 3, 1. sZ.; MNL DL 105992) a budai prépostságnak adományozta Gézavásár vámját, Pest és Kerepes kikötőinek vámját, továbbá a hajóvámot, valamint megerősítette a halászat jogát a Megyer és a Nagy- (Csepel-) sziget közötti Duna-szakaszon, amelyet még Szent László király adományozott (KuBINYI, 1964, 87-89; MagYar, 1991, 156; az azonosítás problémáiról: VÉGH, 2006, 23-24).

A mai Lukács és Császár fürdő környéki hőforrások miatt Hévíznek nevezett területen eredetileg a budai királyi udvarhoz tartozó szolgáltató népek éltek. Változás a 12. század végén következett be, amikor 1187ben III. Orbán pápa jóváhagyta a II. Géza király által Jeruzsálemben alapított stefanita ispotályos rendet, és megerősítette kiváltságait, többek között a hévízi Szentháromság-egyházat, amelyet III. Béla király adományozott a kereszteseknek. 1211-ben Hévíz már független volt Budától, északi határa pedig az aquincumi legiotábortól délre található első mérföldkőig tartott. Délen a tatárjárás előtt a Várhegy északi kétharmada is a felhévízi egyház hatósága alá tartozott (VÉGH, 2006, 22-24). Később a határai módosultak. Északon a melegvízforrásoknál működő malmokkal zárult úgy, hogy a malmok és az itt található fürdők még hozzá tartoztak. Déli határa pedig a mai Bem József utca vonalánál húzódott (KuBINYI, 1964, 142-148). Északon 
- a Malom-tó és a mai Lukács és Császár fürdő környezetében - fürdök és malmok terültek el. Malmai voltak a királynak, a budai káptalannak, továbbá az óbudai és a szigeti apácáknak (KUBINYI, 1964, 129-137). Ezek a malmok különösen fontos bevételi forrást jelentettek a birtokosaiknak, mivel a hőforrások miatt télen is használhatóak voltak. A malmok a későbbi Lőpormalom területén helyezkedhettek el (PAPP, 2015, 108), de említést kell tennünk még a Szentlélek-ispotályról is, amely ugyancsak a melegvizes fürdő miatt jött létre itt. A hódoltság kori Veli bej fürdőtől keletre folytatott 2008-as ásatás során előkerült temető (PAPP, 2008, 158, 48. sz.) alapján az ispotály a Császár fürdőtől délre, a Duna-part felé elnyúlva állhatott (PAPP, 2015, 106).

Az Irgalmasrend építkezésén 1906-ban, az akkori járószint alatt 2 méterrel találták meg a Szentháromság-templom falait. A Margit körút 5. szám alatt akkor már folyt az építkezés, ezért ásatásra nem, csupán az emlékek dokumentálására volt mód (ÉBER, 1906; SUPKA, 1907). A templom már a stefaniták elött is létezett. A rend 1439-ig követhető itt, majd 1445-től a konventet társaskáptalanná alakították át (KUBINYI, 1964, 115-121; Boroviczény, 1991-1992; RoMHÁNyi, 2000, 31). A hozzá tartozó káptalansor a mai Török utcában lehetett (KUBINYı, 1964, 148). A templomtól északra fallal körülvett temető húzódott, ettől északészakkeletre voltak a mészárosok. A Dunához kapcsolódó egyik fontos átkelőhely, a jenői rév az Üstökös és a Vidra utca közé helyezhető. A kikötő valószínűleg északabbra lehetett, ennek régészeti nyomai az ásatásunkon nem kerültek elő. A forrásokban szerepel még egy trágyadomb is, ahol a pesti hajósok kiköthettek, amely a Margit hídtól délre, a mai Bodrog utca táján lehetett (KUBINYI, 1964, 109-110, 148). A terület középkori topográfiájának megértéséhez feltétlenül el kell mondani, hogy a korabeli Duna körülbelül az Árpád fejedelem útja vonalában folyt (11. kép).

A hódoltság korában a tabáni településhez hasonló városrész épült ki a felső hévizek táján is (FEKETE, 1944, 95-97). Legfontosabb építménye a Lőpormalom volt, amelyet vagy Arszlán pasa vagy Szokullu Musztafa pasa építtetett nem sokkal a 16. közepe után (PAPP, 2015). Az épületet törökül Baruthanenak

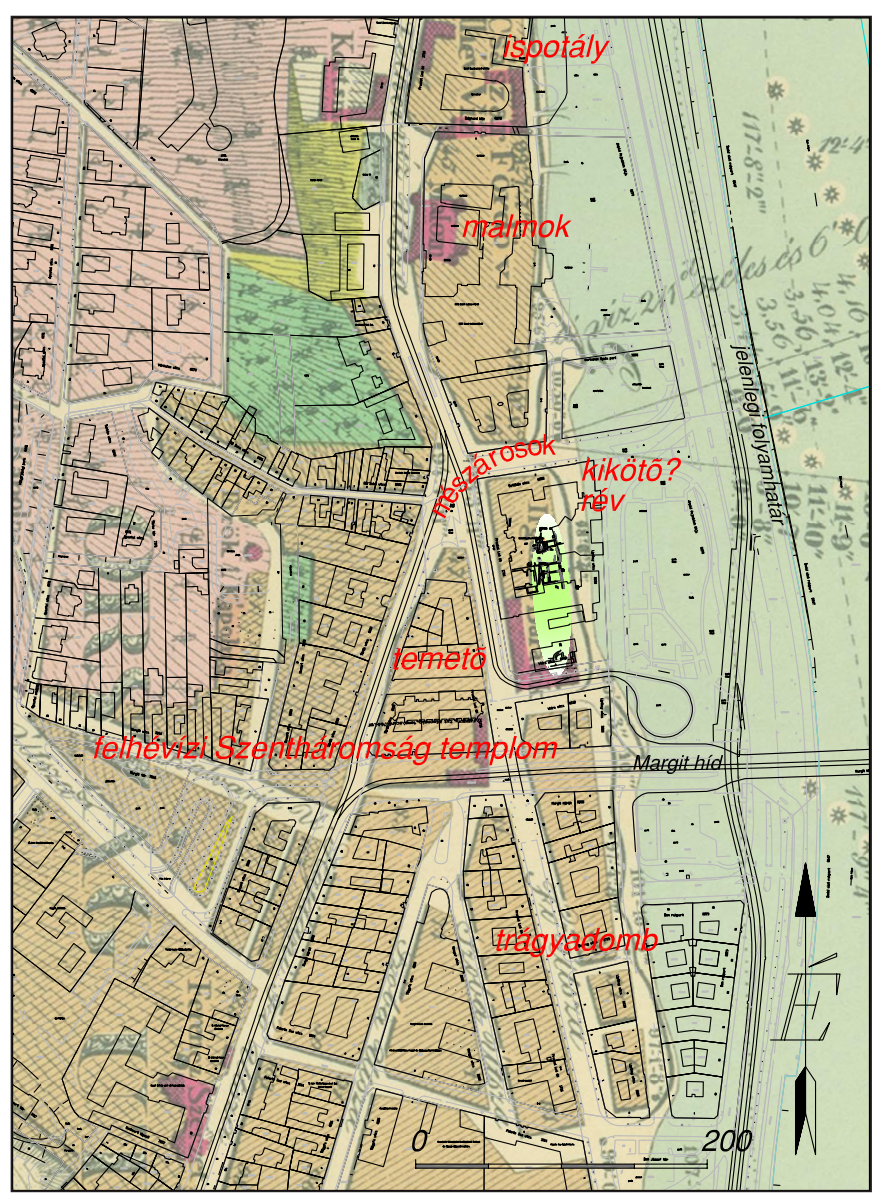

11. kép. Az ásatás helyszine és környezete a középkori topográfiával kiegészítve, Vörös László Buda és Pest 1833-as alap-és vizrajzi térképére vetítve (rajz: Viemann Zs.)

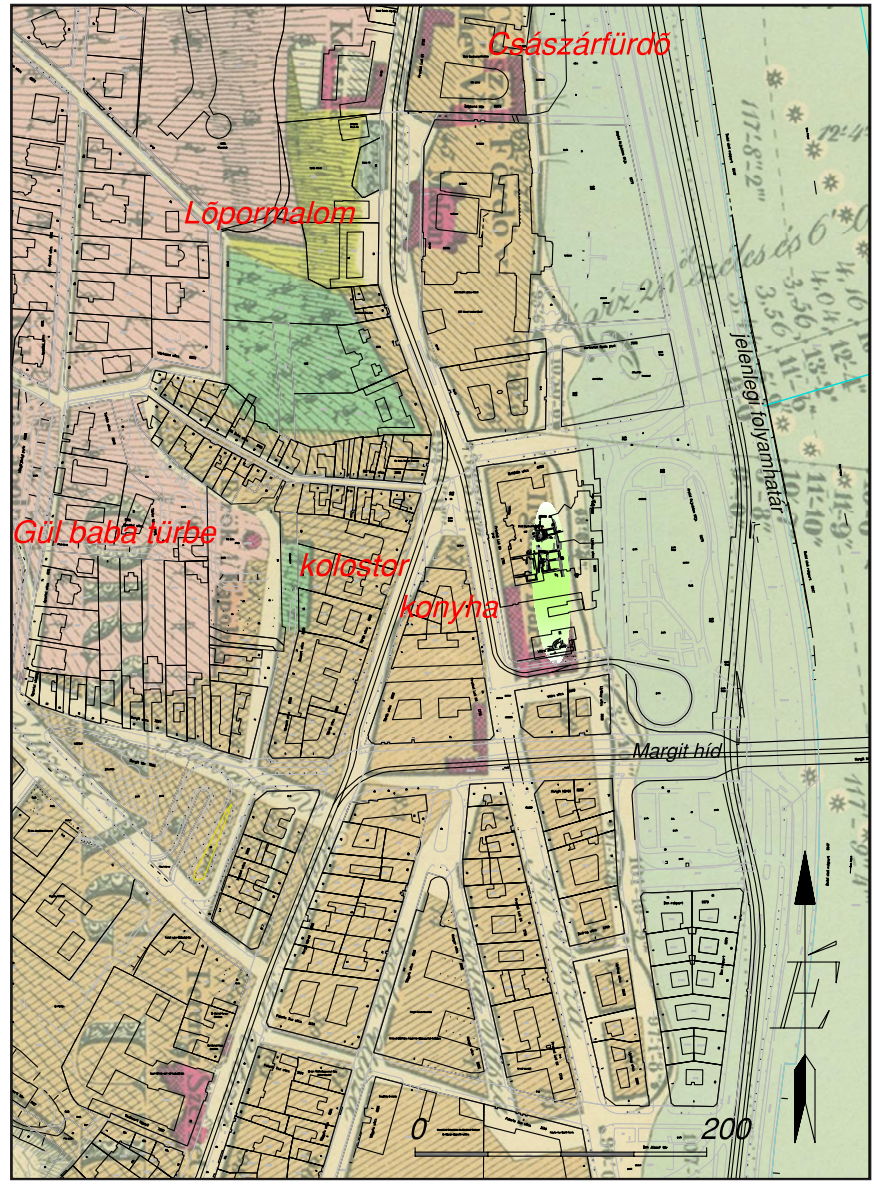

12. kép. Az ásatás helyszine és környezete a török kori topográfiával kiegészitve, Vörös László Buda és Pest 1833-as alap-és vizrajzi térképére vetitve (rajz: Viemann Zs.) 
Bencze Zoltán - Fényes Gabriella - Kurunczi Mónika • Évezredek a talpunk alatt

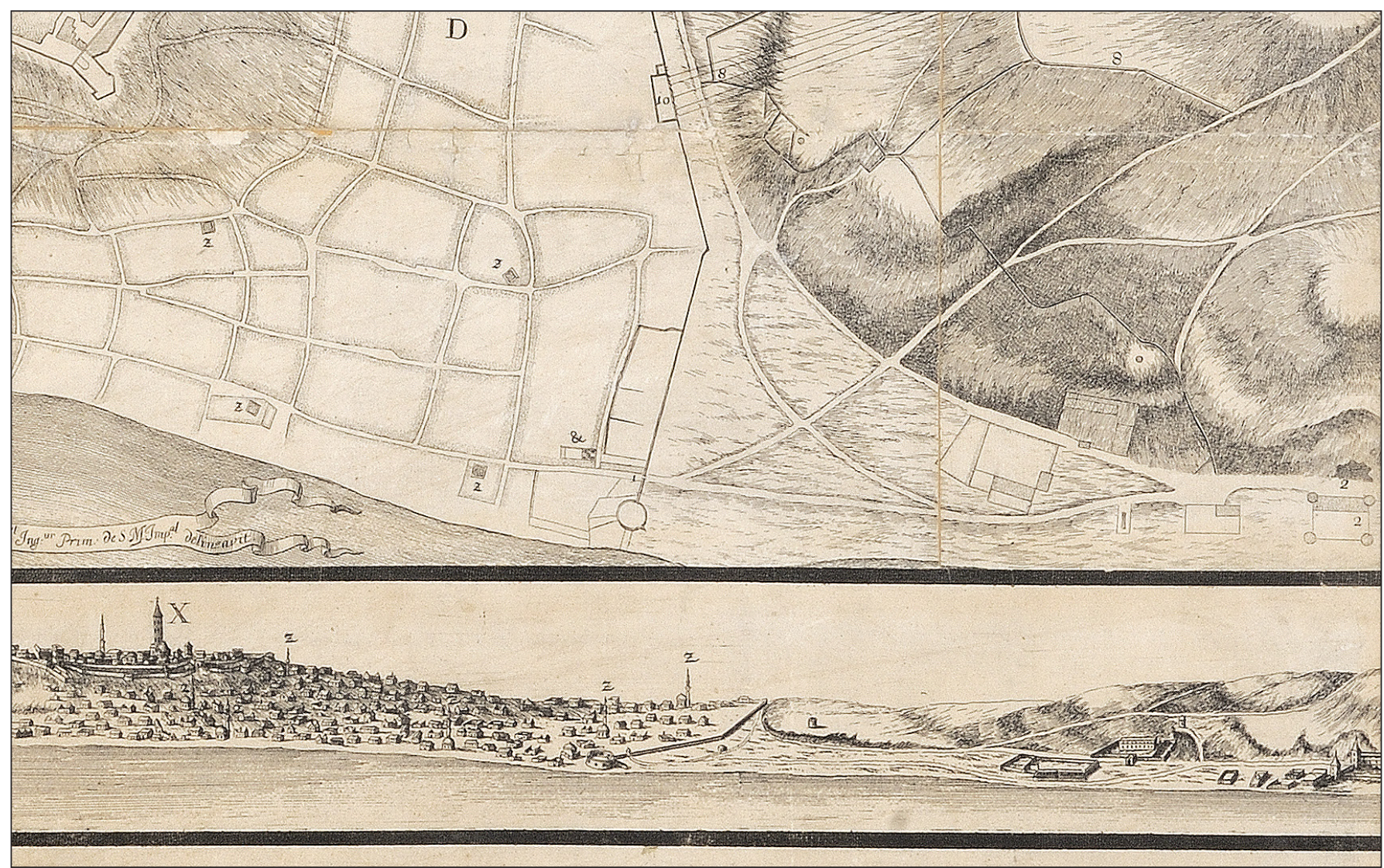

13. kép. Nicolas Marcel de La Vigne Buda és Pest 1686-os térképének részlete

nevezték, és a városrészt is így emlegették. A Lőpormalom mellett állt Szokullu Musztafa mecsetje (SuDÁR, 2014, 225-226). A Lőpormalomtól északra építtette fel 1578-ban Szokullu Musztafa pasa a fürdőt, amely meglepő módon nem az építtető nevét viseli, hanem Veli bej fürdőnek hívják (PAPP, 2018, 85). A közelben a 16. században emelt Gül Baba türbe ma is áll Budapest egyik legfontosabb oszmán-török emlékeként (ÁGOSTON \& SUdÁr, 2002, 71-74). A Török utca - Gül Baba utca sarkán építették fel a Gül Baba derviskolostort; ennek különálló épületében volt a szegénykonyhája, amelyet a Török utca - Frankel Leó út találkozásánál található kis térre helyezhetünk (Sudár Balázs azonosítása; 12. kép). Nem tudjuk, hogy déli irányban a Duna-parton meddig nyúlt el a hódoltság kori település, a nyomait valószínúleg az 1598-as és az 1602-1603-as ostromok tüntethették el (FeKETE, 1944, 33-40). Az 1684-es Hallart-Wening metszeten (RózSA, 1963, Kat. 78; VÉGH, 2015, C.6.3-as térkép) temetőt ábrázolnak ásatási területünk környezetében, és az 1686-os metszeteken sem látunk itt épületeket (lásd pl. Nicolas Marcel de La Vigne 1686-os látképe; 13. kép; RózsA, 1963, Kat. 21, 88, 98; VÉGH, 2015, C.5.1-es térkép).

\section{A LELŐHELY A RÓMAI KORI TOPOGRÁFIÁBAN}

Az Irgalmasrendi Kórház udvarának területe az aquincumi legiotábortól kb. 2,8 km-re, délre és a korai ala tábor feltételezett helyétől (KÉRDÖ, 2003, 81-82) kb. 650 m-re, északra helyezkedik el (14. kép). A közelében, a Török utca Frankel Leó út felöli végén 1880-ban, csatornaásás közben igen gazdag mellékletü szarkofágot találtak. A sír mellett, a lóvasúti sínek alatt állítólag római utat is láttak (HAMPEL, 1881, 136-142). A Frankel Leó út 30-34. szám alatt római telepjelenségek, köépület részlete és kút került elö (FACSÁDY, 1994a, 34). ${ }^{1}$ A mai utca mindkét oldaláról több római temetkezés vagy sírkő ismert.

A közeli Lukács és Császár fürdő forrásainak ókori használatára közvetlen adatunk nincs, de az oltárállítási szokásokból feltételezhető. 1479-ben egy olasz humanista a - már ismertetett, az ásatás helyszí- 
Bencze Zoltán - Fényes Gabriella - Kurunczi Mónika • Évezredek a talpunk alatt

nétől délnyugatra álló - Szentháromság-templom előtt lerajzolt egy oltárkövet, melyet Marcus Foviacius Verus (CIL III 3488; TitAq 291) állított a nimfák tiszteletére. Felice Feliciano azt is feljegyezte, hogy ugyanilyen köveket, hasonló felirattal Mátyás király szállíttatott fel innen a budai várba (RitoóKNÉ SzALAY, 1983, 72-73; 1994, 319, 1. kép, 321). A Lukács és a Császár fürdő területéről, valamint annak környékéről Iuppiter Optimus Maximusnak és Silvanusnak állított oltárkövek kerültek elö (CIL III 10419, 3461; TitAq 117, 162, 298). A Római Birodalomban általános szokás volt, hogy gyógyhatású vizeknél isteneknek, nimfáknak hálaképpen oltárt emeltek, így feltételezhető, hogy a források vizét már a római korban használták. Erre utalhat, hogy a Császár fürdő legutóbbi régészeti kutatása során két középkorinál korábbi falat is feltártak, ${ }^{2}$ továbbá a Császár fürdő elbontott nagymedencéje alatt 1992-ben római leletanyagot tartalmazó réteget is megfigyeltek (FACSÁDY, 1994b, 84). ${ }^{3}$ Régebben feltételeztek egy késő római örtornyot a Lukács fürdő területén is (NÉMETH, 2002, 97), ez azonban a török kori löportorony maradványának bizonyult (VARGA, 2011, 119).

A mostani régészeti adatokból látszik, hogy a Duna partján, a meleg vizes források közelében, a minden bizonnyal a római korban is kikötésre, átkelésre alkalmas területen már az 1. század közepe körül megtelepedtek. A 2-3. század folyamán jelentősebb építkezések folytak itt, melynek maradványait az Irgalmasrendi Kórház udvarán végzett ásatásunk hozta a felszínre.

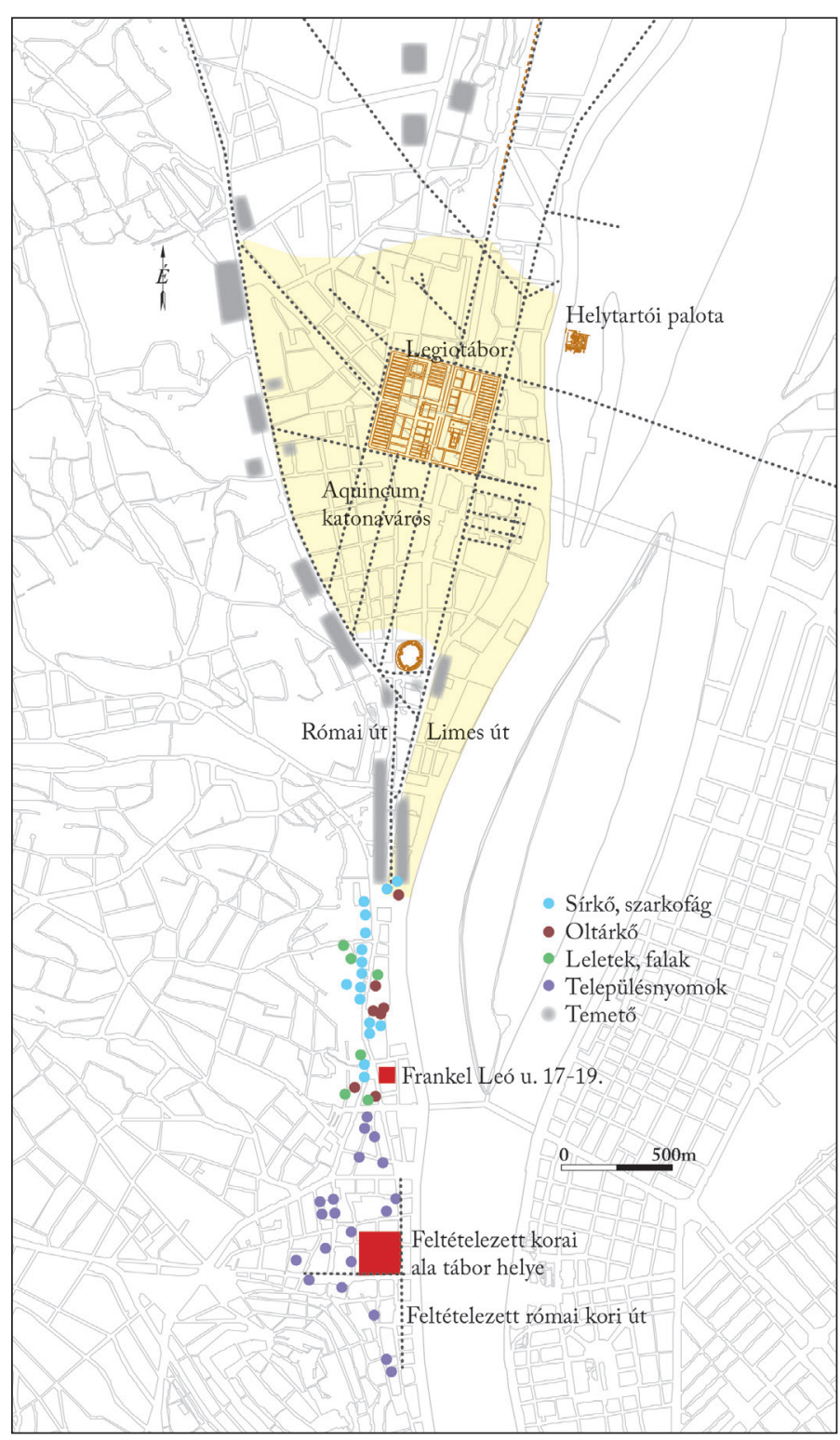

14. kép. A Budai Irgalmasrendi Kórház udvarán folytatott ásatás helyszine a római kori topográfíban (rajz: Kolozsvári K.)

\section{RÖVIDÍTÉSEK}

CIL: Corpus Inscriptionum Latinarum.

MDCBP I: Gyánky, D. \& Gárdonyi, A. (eds.) (1936). Monumenta Diplomatica Civitatis Budapestinensis. Tomus I. (1148-1301). Budapest.

MNL DL: Magyar Nemzeti Levéltár Diplomatikai Levéltára.

TitAq: Kovács, P. \& Szabó, Á. (eds.) (2009). Tituli Aquincenses. Vol. I. Budapest: Pytheas.

\footnotetext{
Papp Adrienn szíves szóbeli közlése, 2019. december 10.

3 R. Facsády Annamária 1992. évi ásatása (BTM Régészeti Adattár ltsz. 1723-93).
} 
Bencze Zoltán - Fényes Gabriella - Kurunczi Mónika • Évezredek a talpunk alatt

BiBLIOGRÁFIA

Ágoston, G. \& Sudár, B. (2002). Gül Baba és a magyarországi bektasi dervisek. Budapest: Terebess Kiadó.

Boroviczény, K. Gy. (1991-1992). Cruciferi Sancti Regis Stefani. Tanulmányok a stefaniták, egy középkori magyar ispotályos rend történetéröl. Orvostörténeti Közlemények 133-140, 7-48.

Éber, L. (1906). A budafelhévízi Szentháromság templom maradványai. Budapest Régiségei 9, 209-211.

Facsády, A. (1994a). Nr. 50/1, Frankel Leó u. 30-34. Régészeti Füzetek 1 (46), 34.

Facsády, A. (1994b). Nr. 121/6, Frankel Leó u. 35. (Császárfürdő). Régészeti Füzetek 1 (46), 84.

Gyánky, D. \& Gárdonyi, A. (eds.) (1936). Monumenta Diplomatica Civitatis Budapestinensis. Tomus I. (1148-1301). Budapest.

Hampel, J. (1881). Római sírok Pannoniában. Archaeologiai Értesítő, Új évfolyam 1, 136-146.

Kérdő, K. (2003). Das Alenlager und Vicus der Víziváros. In P. Zsidi (ed.), Forschungen in Aquincum 1969-2002 (pp. 112-119). Aquincum Nostrum II. 2. Budapest: Budapesti Történeti Múzeum.

Kovács, P. \& Szabó, Á. (eds.) (2009). Tituli Aquincenses. Vol. I. Budapest: Pytheas.

Kubinyi, A. (1964). Budafelhévíz topográfiája. Tanulmányok Budapest Múltjából 16, 85-170.

Magyar, K. (1991). Gründung Budas. In G. Biegel (ed.), Budapest im Mittelalter (pp. 153-184). Braunschweig: Braunschweigisches Landesmuseum.

Németh, M. (2003). Wachtürme und Festungen am linken Donauufer. In P. Zsidi (ed.), Forschungen in Aquincum 1969-2002 (pp. 96-99). Aquincum Nostrum II. 2. Budapest: Budapesti Történeti Múzeum.

Papp, A. (2008). Budapest, II. Árpád fejedelem útja, Császár fürdő. In Kisfaludi, J. (szerk.), Régészeti kutatások Magyarországon 2008 (p. 158, 48. kat.). Budapest: Kulturális Örökségvédelmi Hivatal - Magyar Nemzeti Múzeum.

Papp, A. (2015). Török kori lőpormalom Budán. Keletkutatás 1, 105-113.

Ritoókné Szalay, Á. (1983). Nympha super ripam Danubii. Irodalomtörténeti Közlemények 87, 67-74.

Ritoókné Szalay, Á. (1994). A római föliratok gyüjtői Pannoniában. In Mikó Á. \& Takács I. (szerk.), Pannonia Regia. Müvészet a Dunántúlon 1000-1541 (pp. 318-329). Budapest: Magyar Nemzeti Galéria.

Romhányi, B. (2000). Kolostorok és társaskáptalanok a középkori Magyarországon. Budapest: Pytheas.

Rózsa, Gy. (1963). Budapest régi látképei. Monumenta Historia Budapestinensia 2. Budapest: Akadémiai Kiadó.

Sudár, B. (2014). Dzsámik és mecsetek a hódolt Magyarországon. Budapest: MTA Bölcsészettudományi Kutatóközpont Történettudományi Intézet. 
Bencze Zoltán - Fényes Gabriella - Kurunczi Mónika • Évezredek a talpunk alatt

Supka, G. (1907). A budafelhévízi Szentháromság templom. Archaeologiai Értesítő 27, 97-119.

Varga, G. (2011). Római kori őrtornyok Budapesten. Archaeologiai Értesítö 136, 115-134. http://dx.doi. org/10.1556/ArchErt.136.2011.5

Végh, A. (2006). Buda város középkori helyrajza 1. Monumenta Historia Budapestinensia 15. Budapest: Budapesti Történeti Múzeum - Archaeolingua.

Végh, A. (2015). Buda. I. kötet, 1686-ig. Magyar Várostörténeti Atlasz 4. Budapest: Budapesti Történeti Múzeum - Pázmány Péter Katolikus Egyetem. 